\title{
The Other Death Penalty in Canada?
}

Convict 777

\section{THE LIFE SENTENCE}

Canada is a progressive country. We have medicare, welfare, socialized elementary and secondary education. We have all the markings of a great nation, so why the life sentences? It is not a disgusting, destructive, inhumane tool? In fact, it could be argued that the life sentence is no different than the death penalty (Hartman, 2013), which we abolished years ago in this country. Why must Canada continue to hold on to such a tarnishing, evil thing? A true progressive democracy does not need life sentences or the death penalty. Canada should move away from following broken examples like the United States (ibid). Instead, we should concentrate on countries like Portugal (Constitution of the Portuguese Republic, art. $30, \S 1)$. If we are to be as advanced on the world stage as we think we are, then we must abolish the life sentence, not in 10 years or 20 years, but now. This cannot wait. One must choose a more humanitarian way than what we have chosen at present.

\section{HALFWAY HOUSES}

How is it that there is no room for prisoners getting out of jail in the halfway houses? I think there must be less construction of super prisons and more construction of halfway houses. It is not only extremely cost effective to stop imprisoning people, but it is timely as people here have to wait long periods of time in prison while they search for bed space. This is ridiculous! How are prisoners supposed to rehabilitate and rebuild their lives when we are not given the proper tools for success? When a prisoner fails, society also fails and suffers the consequences.

\section{INNOCENT PEOPLE IN PRISON}

I have been in prison for some time now and I have come to meet people from all walks of life. The one group of people that causes me the most distress when I think about their being incarcerated are the innocent. These are not people that are lying or faking. They are not trying to fight the system and they have surrendered themselves to it; broken, hopeless and confused. It freaks me out because how can this happen in Canada? I am sure these 
people did not think it would have happened to them. As a convict that has been around for as long as I have, I can very easily read other convicts and prisoners. So trust me when I tell you that there are innocent people in prisons. Perhaps the government should create a program or some kind of watchdog force that can look closely at people that were found guilty of murder. I thought that was crazy, until I started meeting all of these innocent people behind bars. If innocent people are to remain in prison, then the whole system is truly in disrepute.

\section{REFERENCES}

Constitution of the Portuguese Republic (1989) "Art. 30, § 1: Limits on Sentences and Security Measures". Retrieved from https://dre.pt/part-i.

Hartman, Kenneth (2013) Too Cruel, Not Unusual Enough: An Anthology Published by the Other Death Penalty Project, Lancaster: The Steering Committee Press.

\section{ABOUT THE AUTHOR}

Convict 777 is imprisoned at Archambault Institution. 